\title{
Approximating fixed points of enriched nonexpansive mappings in Banach spaces by using a retraction-displacement condition
}

\section{VASILE BERINDE}

\begin{abstract}
.
In this paper, we prove convergence theorems for a fixed point iterative algorithm of Krasnoselskij-Mann type associated to the class of enriched nonexpansive mappings in Banach spaces. The results are direct generalizations of the corresponding ones in [Berinde, V., Approximating fixed points of enriched nonexpansive mappings by Krasnoselskij iteration in Hilbert spaces, Carpathian J. Math., 35 (2019), No. 3, 293-304.], from the setting of Hilbert spaces to Banach spaces, and also of some results in [Senter, H. F. and Dotson, Jr., W. G., Approximating fixed points of nonexpansive mappings, Proc. Amer. Math. Soc., 44 (1974), No. 2, 375-380.], [Browder, F. E., Petryshyn, W. V., Construction of fixed points of nonlinear mappings in Hilbert space, J. Math. Anal. Appl., 20 (1967), 197-228.], by considering enriched nonexpansive mappings instead of nonexpansive mappings. Many other related results in literature can be obtained as particular instances of our results.
\end{abstract}

\section{REFERENCES}

[1] Berinde, V., Iterative approximation of fixed points, Second edition. Lecture Notes in Mathematics, 1912, Springer, Berlin, 2007

[2] Berinde, V., Weak and strong convergence theorems for the Krasnoselskij iterative algorithm in the class of enriched strictly pseudocontractive operators, An. Univ. Vest Timiş. Ser. Mat.-Inform., 56 (2018), No. 2, 13-27

[3] Berinde, V., Approximating fixed points of enriched nonexpansive mappings by Krasnoselskij iteration in Hilbert spaces, Carpathian J. Math., 35 (2019), No. 3, 293-304

[4] Berinde, V., Khan, A. R. and Păcurar, M., Coupled solutions for a bivariate weakly nonexpansive operator by iterations, Fixed Point Theory Appl., 2014, 2014:149, 12 pp.

[5] Berinde, V. and Păcurar, M., An iterative method for approximating fixed points of Prešić nonexpansive mappings, Rev. Anal. Numér. Théor. Approx., 38 (2009), No. 2, 144-153

[6] Berinde, V. and Păcurar, M., Fixed point theorems for Kannan type mappings with applications to split feasibility and variational inequality problems (submitted)

[7] Berinde, V. and Păcurar, M., Approximating fixed points of enriched Chatterjea contractions by Krasnoselskij iterative algorithm in Banach spaces (submitted)

[8] Berinde, V. and Păcurar, M., Approximating fixed points of enriched contractions in Banach spaces (submitted)

[9] Berinde, V. and Păcurar, M., Approximating fixed points of enriched contractive type mappings in convex metric spaces (submitted)

[10] Berinde, V., Petruşel, A., Rus, I. A. and Şerban, M., The Retraction-Displacement Condition in the Theory of Fixed Point Equation with a Convergent Iterative Algorithm, Mathematical analysis, approximation theory and their applications, 75-106, Springer Optim. Appl., 111, Springer, [Cham], 2016

[11] Browder, F. E., Nonexpansive nonlinear operators in a Banach space, Proc. Nat. Acad. Sci. U.S.A., 54 (1965), 1041-1044

Received: 31.10.2019; In revised form: 20.11.2019; Accepted: 10.12.2019

2010 Mathematics Subject Classification. 47H05, 47H10, 54H25.

Key words and phrases. Banach space, enriched nonexpansive mapping, fixed point, iteration. 
[12] Browder, F. E., Fixed point theorems for nonlinear semicontractive mappings in Banach paces, Arch. Rational Mech. Anal., 21 (1966) 259-269

[13] Browder, F. E., Convergence of approximants to fixed points of nonexpansive nonlinear maps in Banach spaces, Arch. Rat. Mech. Anal., 24 (1967), 82-90

[14] Browder, F. E., Nonlnear mappings of nonexpansive and accretive type in Banach spaces, Bull. Amer. Math. Soc., 73 (1967), 875-882

[15] Browder, F. E., Semicontractive and semiaccretive nonlinear mappings in Banach spaces, Bull. Amer. Math. Soc., 74 (1968), 660-665

[16] Browder, F. E. and Petryshyn, W. V., The solution by iteration of nonlinear functional equations in Banach spaces, Bull. Amer. Math. Soc., 72 (1966), 571-575

[17] Browder, F. E. and Petryshyn, W. V., Construction of fixed points of nonlinear mappings in Hilbert space, J. Math. Anal. Appl., 20 (1967), 197-228

[18] Bruck, R. E., Asymptotic behavior of nonexpansive mappings, Contemporary Mathematics, 18, Fixed Points and Nonexpansive Mappings, (R.C. Sine, Editor), AMS, Providence, RI, 1980

[19] Chidume, C., Geometric properties of Banach spaces and nonlinear iterations, Lecture Notes in Mathematics, 1965. Springer-Verlag London, Ltd., London, 2009

[20] Dotson, W. G., Jr., On the Mann iteration process, Trans. Amer. Math. Soc., 149 (1970), 65-73

[21] Dotson, W. G., Jr., Fixed points of quasi-nonexpansive mappings, J. Austral. Math. Soc., 13 (1972), 167-170

[22] Edelstein, M., A remark on a theorem of M. A. Krasnoselski, Amer. Math. Monthly, 73 (1966), 509-510

[23] Fukhar-ud-din, H. and Berinde, V., Fixed point iterations for Prešić-Kannan nonexpansive mappings in product convex metric spaces, Acta Univ. Sapientiae Math., 10 (2018), No. 1, 56-69

[24] Fukhar-ud-din, H., Berinde, V. and Khan, A. R., Fixed point approximation of Prešić nonexpansive mappings in product of $C A T(0)$ spaces, Carpathian J. Math., 32 (2016), No. 3, 315-322

[25] Groetsch, G. W., A note on segmenting Mann iterates, J. Math. Anal. Appl., 40 (1972), 369-372

[26] Kannan, R., Some results on fixed points. Ill, Fund. Math., 70 (1971), 169-177

[27] Krasnosel'skii, M. A., Two remarks about the method of successive approximations (Russian), Uspehi Mat. Nauk (N.S.), 10 (1955), No. 1(63), 123-127

[28] Krasnoselski, M. A., Two remarks on the method of successive approximations (Romanian), Acad. R. P. Romîne An. Romîno-Soviet. Ser. Mat. Fiz., (3) 10 (1956), No. 2(17), 55-59

[29] López, G., Martín-Márquez, V. and Xu, H.-K., Halpern's iteration for nonexpansive mappings, Nonlinear analysis and optimization I. Nonlinear analysis, 211-231, Contemp. Math., 513, Israel Math. Conf. Proc., Amer. Math. Soc., Providence, RI, 2010

[30] Opial, Z., Nonexpanslve and monotone mappings in Banach spaces, Center for Dynamical Systems, Division of Applied Math., Brown University, Lecture Notes, 67-1, 1967

[31] Outlaw, C. L., Mean value iteration of nonexpansive mappings in a Banach space, Pacific J. Math., 30 (1969), 747-750

[32] Petryshyn, W. V., Construction of fixed points of demicompact mappings in Hilbert space, J. Math. Anal. Appl., 14 (1966), 276-284

[33] Reich, S., Some remarks concerning contraction mappings, Canad. Math. Bull., 14 (1971), 121-124

[34] Rus, I. A., The generalized retraction methods in fixed point theory for nonself operators, Fixed Point Theory, 15 (2014), 559-578

[35] Schaefer, H., Über die Methode sukzessiver Approximationen (German), Jber. Deutsch. Math. Verein., 59 (1957), Abt. 1, 131-140

[36] Senter, H. F. and Dotson, Jr., W. G., Approximating fixed points of nonexpansive mappings, Proc. Amer. Math. Soc., 44 (1974), No. 2, 375-380

\author{
Department of MATHEMATICS AND COMPUTER SCIENCE \\ TECHNICAL UNIVERSITY OF CLUJ-NAPOCA \\ North UnIVERSITY CENTRE AT BAIA MARE \\ VICTORIEI 76, RO-430122 BAIA MARE, ROMANIA \\ Email address: vberinde@cunbm. utcluj.ro
}

